\title{
Alejo Carpentier, The Harp and the Shadow: Literature, History and Fiction
}

\author{
Rodica Grigore ${ }^{1}$
}

Not entirely a historical text, The Harp and the Shadow, the last novel published by Alejo Carpentier, takes as its pretext certain historical data in order to offer the readers a specific view of the protagonist, Christopher Columbus. Considered by some the great discoverer of the New World or highly regarded as "The Admiral of the Seas" and despised by many others as an adventurer and a liar, Columbus is also the author of some disturbing writings that still put critics and literary historians in discomfort. This is the novel's point of departure, together with the intent of Pope Pius IX to initiate the canonization of Columbus, an idea regarded by the great majority of his contemporaries as a complete blasphemy. At the aesthetic level, comparable up to a certain point to the conception of Jorge Luis Borges, Carpentier's form of understanding and practicing literature is always, in a more or less obvious way, reliant on Cervantes himself. But it is not limited to Don Quixote: in The Harp and the Shadow, the Cuban author builds an endless network of intertextual associations connecting his own creation to The Works of Persiles and Segismunda, the last work by Cervantes. [Article copies available for a fee from The Transformative Studies Institute. E-mail address: journal@transformativestudies.org Website: http://www.transformativestudies.org (C2021 by The Transformative Studies Institute. All rights reserved.]

KEYWORDS: Latin American Literature, History, Fiction, Reality, Aesthetic Truth, Illusion.

\footnotetext{
${ }^{1}$ Rodica Grigore, Ph.D., is senior lecturer in Comparative Literature at "Lucian Blaga" University of Sibiu, Romania. She is the author of several critical studies: Despre cărţi şi alţi demoni [Of Books and Other Demons, 2002], Retorica măştilor în proza interbelică românească [The Rhetoric of Masks in Romanian Modern Fiction, 2005], Lecturi in labirint [Readings in the Labyrinth, 2007], Măşti, caligrafie, literatură [Masks, Calligraphy, Literature, 2011], In oglinda literaturii [In the Mirror of Literature, 2011], Meridianele prozei [Fiction's Meridians, 2013], Pretextele textului [The Pretexts of the Text, 2014], Realismul magic în proza latino-americană a secolului XX. [Magical Realism in Latin-American Fiction of the $20^{\text {th }}$ Century, 2015], Călătorii în bibliotecă. Eseuri [Journeys in the Library. Essays, 2016], Cărți, vise și identități în mișcare. Eseuri despre literatura contemporană [Books, Dreams and Changing Identities. Essays on the Contemporary Literature, 2018]. She has also translated into Romanian the essays of Octavio Paz, Children of the Mire, (2003/2017). Between 2005 and 2012 she has been coordinating the anthology of The International Theatre Festival of Sibiu. She has published numerous essays and critical studies especially on modern literature in Romania and abroad. Address correspondence to: Rodica Grigore, e-mail: rodica.grigore@gmail.com.
} 